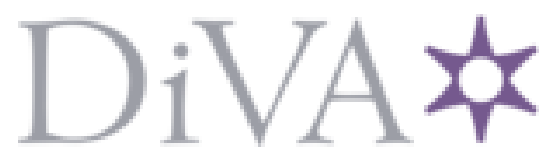

http://www.diva-portal.org

\title{
Postprint
}

This is the accepted version of a chapter published in Theoretical Perspectives on Family Businesses.

Citation for the original published chapter:

Waldkirch, M. (2015)

Social identity theory and the family business.

In: Mattias Nordqvist, Leif Melin, Matthias Waldkirch and Gershon Kumeto (ed.), Theoretical

Perspectives on Family Businesses (pp. 137-155). Edward Elgar Publishing

https://doi.org/10.4337/9781783479665.00015

N.B. When citing this work, cite the original published chapter.

Permanent link to this version:

http://urn.kb.se/resolve?urn=urn:nbn:se:hj:diva-29156 


\section{Social Identity Theory and the Family Business}

\section{Matthias Waldkirch}

\section{Introduction}

The research on identity, "one of the most commonly studied constructs in the social sciences” (Vignoles, Schwartz, \& Luyckx, 2011, p. 1), addresses one of the oldest questions of humanity: "Who are you?". Depending on how the question is answered, identity can be an individual, relational or collective construct, encompassing persons, social categories or organisations, such as churches or multinational enterprises. One of the most compelling theories about identity as a collective construct was derived by Henri Tajfel and John Turner (Tajfel, 1972; Tajfel \& Turner, 1979; Turner, 1984). Their work on Social Identity Theory (SIT) has influenced many different streams of research, for instance, psychology, sociology and organisational research. Their primary contribution was to link personal identity to membership in social groups or categories. Groups are hence seen as an internalised part of identity and "contribute to a person's sense of self” (Haslam, 2004, p. 14).

"[...] we do not act as isolated individuals but as social beings who derive an important part of our identity from the human groups and social categories we belong to; and we act in accordance with this awareness.” (Tajfel, Fraser, \& Jaspars, 1984, p. 5)

Adapted to the organisational context by Ashforth and Mael (1989), SIT today is commonly used in management and business studies (Hogg \& Terry, 2000; Reicher, Spears, \& Haslam, 2010) in which it functions, for instance, as a way to explain both intra- and interorganisational group behaviour. SIT has also recently been adapted by family business research (for instance, Deephouse \& Jaskiewicz, 2013; Shepherd \& Haynie, 2009; Zellweger, Eddleston, \& Kellermanns, 2010). Issues of identity are central to the way family firms are 
portrayed and defined and allow new insights to be gained into the "meaning structures of the family and business components of a 'family business'” (Whetten, Foreman, \& Dyer, 2014, p. 480). Social identity, for instance, is essential for the classic depiction of family firms as a system of overlapping circles of family, business and ownership (Tagiuri \& Davis, 1992) as well as for distinct concepts about family firms, such as socioemotional wealth (GómezMejía, Haynes, Núñez-Nickel, Jacobson, \& Moyano-Fuentes, 2007; see also the chapter by Kumeto). Accordingly, the social identity construct could further our understanding of issues, such as conflicting identities in family firms. In this chapter, I will firstly introduce SIT and its origins, going briefly into its application in organisational research. The second part will review the current research utilising SIT in the area of family businesses. In the third part, I will propose future research opportunities for SIT in the context of family firms, proposing furthermore a possible methodology. Concluding the chapter, I will note some limitations before outlining how family businesses as a context could help advance SIT.

\section{Social Identity Theory}

Identity was introduced as a core concept to the social sciences in the 1950s (Gleason, 1983). In the subsequent centuries, identity research has grown in both scope and importance (Vignoles et al., 2011). Yet, until today, there was no overarching definition of the term ‘identity’ and what it encompasses (Wetherell, 2010). In researching identity, there are several paths to gaining insights depending on the unit of analysis. Sedikides and Brewer (2001) argue that identity can be seen on an individual, relational, or collective level. Wetherell (2010), however, sees different paths for identity research through the inquiry of identity as a subjective individual achievement, according to membership in social groups, and from an ethical and political point of view. These various levels and paths refer to differences both in forms of identity content as well as in the identity formation processes (Vignoles et al., 2011). Looking at where SIT is situated, it is generally seen as part of the collective identity research, 
trying to give "an integrated answer to the problem of the individual and the social” (Wetherell, 2010, p. 11). Tajfel and Turner (1979) made the distinction early on between personal identity, concerned with person-specific characteristics, such as interests or bodily attributes, and social identity. As Abrams and Hogg argue, personal and social identity are at “opposite ends of a single continuum” (2010, p. 183), and this chapter will focus on the social identity end.

According to Tajfel and Turner, social identity consists of "those aspects of an individual's self-image that derive from the social categories to which he [sic] perceives himself as belonging” (1979, p. 40). The authors see social categories as cognitive tools through which individuals can classify the social environment; typical categories could be age, gender or ethnicity. Individuals thus have in-groups to which they belong or perceive that they belong. Turner proposed that "a collection of people who share the same identification or define themselves in terms of the same social category membership” (Turner, 1984, p. 530) would form such a ‘psychological group’. Hence, as Ashforth and Mael (1989) note, SIT provides a partial answer to the question of 'who am I' by linking identity to group categorisations. At the fundament of SIT, Tajfel and Turner (1979) express three general assumptions.

1. Individuals aim to enhance or maintain their self-esteem, thus striving for a positive self-concept.

2. Social groups are associated with positive or negative connotations; accordingly, groups that contribute to an individual's social identity influence it in a positive or negative way.

3. One’s own groups are evaluated through comparison to other groups, leading either to high or low prestige.

Out of these assumptions, Tajfel and Turner derive related theoretical principles. Individuals strive for a positive social identity, which is in large part generated through a favourable 
comparison between the in-group and some relevant out-group. For such a comparison, the ingroup must be perceived as distinct from the out-group. If the comparison is negative, individuals will either try to leave the group they belong to or try to heighten the positive image of their group. Such pressure for positive comparison leads to groups making an effort to differentiate themselves from other groups. Furthermore, Tajfel and Turner outline three variables that influence intergroup differentiation.

1. Individuals need to have internalised their group membership to the point that it becomes part of their self-concept; being defined by others as a member of a group is not enough, even though such pressure could become a causal factor for a group's self-definition.

2. The social situation must allow for an intergroup comparison. Tajfel and Turner name, for instance, language as an important dimension for intergroup comparison in multilingual countries, such as Belgium or Wales, whereas in monolingual countries, such as Poland or Germany, this category is less salient.

3. The in-group does not compare itself to every out-group; therefore, the out-group must be perceived as being a relevant comparison group.

The origin of SIT is the work on categorisation and discrimination by Henri Tajfel (Tajfel, 1969, 1970) and the 'minimal group studies' that Tajfel conducted with Flament, Billig and Bundy (1971). These studies looked at the necessary conditions to produce negativity against an out-group. Tajfel, having survived the holocaust in Europe, was driven to understand the "nature of prejudice” (Billig, 2002, p. 176). Looking at status inequality, Billig, a former colleague of Tajfel, makes a point when noting that social identity theory "is, at root, a theory of group freedom” (2002, p. 179). Accordingly, two often used examples by Tajfel were the feminist and the Afro-American movements. With his seminal work on SIT (Tajfel, 1972), Tajfel moved away from the perception of prejudice and stereotyping to include a concept of 
self in society created by social categorisations. The theory of social identity was, with the help of John Turner (Tafel \& Turner, 1979), refined over the years and extended, for instance, through self-categorisation theory and prototyping (Hogg \& Terry, 2000). This addition to SIT proposes that individuals categorise themselves according to group prototypes, "fuzzy sets that capture the context-dependent features of group membership” (Hogg \& Terry, 2000, p. 123). Such social categorisation could lead to a depersonalisation of the self as well as of out-group members, as prototypes "maximize similarities within and differences between groups” (2000, p. 124).

Considering the history of SIT and different aspects, such as intergroup conflict or prototyping, it becomes clear that power plays a potentially important role. In their review on power in organisational research, Fleming and Spicer (2014) identify 'subjectification' and 'domination’ as two important faces of power. Subjectification, encompassing the influence that determines an “actor’s very sense of self” (2014, p. 244), draws a clear connection between identity, emotions and power. Domination, on the other hand, may play a role in the formulation of social identities in organisations and could be enacted through organisational discourse (Grant, Hardy, Oswick, \& Putnam, 2004). Alvesson and Willmott (2002) in their work on organisational control and identity regulation show how employees are pressured to adhere to an identity deemed congruent with the objectives of management. Although delving into issues of power would go beyond the scope of this chapter, I consider it important to highlight the impact that power has on social identity formulation and group behaviour.

Looking back on the impact of SIT, Brown (2000) argues that the theory has made several important contributions. SIT is able to provide a valid explanation for in-group bias, especially in the absence of objective or goal-oriented reasons, by illuminating the need for a positive group evaluation. Looking further, SIT facilitated the understanding of how members in dominant or subordinate groups react to status inequality. Ellemers (1993) identifies 
variables that influence whether group members display individualist or collectivist behaviour when striving for higher status; individualist behaviour is linked to group members trying to gain access to a higher status group, while collectivist behaviour would lead to individuals trying to improve the relative status of their group. As Tajfel and Turner (1979) expressed, members of low-status groups would try to change their group affiliation to gain higher selfesteem. Such 'individual mobility’, however, is not possible when there is impermeability between groups; one cannot change, for example, skin colour to move from one group to another. In such cases, identification with an in-group is “inevitable” (Ellemers, 1993, p. 32).

In recent years, SIT has progressed both in terms of internal theoretical consistency as well as through its use in new domains (Hornsey, 2008). Looking at the motivational basis of intergroup behaviour, originally self-esteem was seen as the most important driver. Yet, in recent years, the notion of distinctiveness and meaning as motivators has gained in importance (Abrams \& Hogg, 2010). Additionally, uncertainty avoidance has been identified as an important driver of intergroup behaviour (Hogg, 2007) because it addresses the reasons, strength, and time of group identification. Taken to an extreme, the process of uncertainty avoidance through social identity and self-categorisation processes may even lead to group and societal extremism (Hogg \& Adelman, 2013). Another stream of research in SIT focuses on group-level emotions and how different emotions, such as shame (Ellemers, Doosje, \& Spears, 2004) or collective guilt (Wohl, Branscombe, \& Klar, 2006), can predict intergroup behaviour. Furthermore, the link between social identity and intergroup forgiveness has been highlighted over recent years (Hewstone, Cairns, Voci, Hamberger, \& Niens, 2006; Van Tongeren, Burnette, O’Boyle, Worthington, \& Forsyth, 2014). Linked to all of these issues is the topic of changing intergroup attitudes through intergroup contact. For instance, Gaertner and colleagues (1993) proposed a transformation of the perception of group boundaries from an "us vs. them” to a more inclusive "we” perspective, "achieving more harmonious 
intergroup relations” (1993, p. 2). As Brown (2000) however notes, such a diffusion of category boundaries is more difficult and more critical when talking about real-life groups.

Social Identity Theory has fostered much in-depth understanding of how social groups and identity are linked together. SIT represented a "refreshing alternative to established theorising” (Reicher et al., 2010, p. 61) and continues to be a very helpful theory for researchers trying to understand, explain and forecast group behaviour. As Haslam (2004) argues, SIT is a fine-grained paradigm that considers both the analysis of psychological processes and socio-contextual dimensions. With such potential, it was only natural that Ashforth and Mael (1989) adopted SIT to organisations. They used the theory to bring more coherence into the discussion about identity in organisations, looking for instance at antecedents and consequences of social identification in organisations. Ashforth and Mael also used SIT to elucidate organisational phenomena, such as intraorganisational conflict, intergroup relations and organisational socialisation. Even today, SIT has a strong ongoing influence in organisational studies as it has the ability to "enhance our understanding of people within organisational contexts” (Blader \& Tyler, 2009, p. 446).

\section{Social Identity Theory in family business research}

The concept of identity is strongly related to depictions of the influence of the family on the business. As seen in the three circle model with its combination and overlap of the dimensions of family, business and ownership (Gersick, Davis, McCollum Hampton, \& Lansberg, 1997), the actions of family employees carry "both business and family meaning” (Tagiuri \& Davis, 1996, p. 202). Looking furthermore at the research on SIT in family firms, ownership oftentimes is depicted as a discrete social category that is highly intertwined with family membership. Ownership is not seen from a purely functional perspective, i.e., representing that a person holds a certain amount of shares in a company. Rather, the research adds another 
layer of meaning to ownership with the notion of 'emotional ownership', taking the ”nonfinancial aspects of owning a firm” into consideration (Zellweger \& Astrachan, 2008, p. 347). Furthermore, family owners may also derive the "noneconomic benefit of social status" (Chua, Chrisman, \& Steier, 2003, p. 332) from their ownership status. Such versatility of ownership as a category or social group makes family firms an interesting field of research for SIT.

SIT in family firm research has grown in importance as it is used both as the main theoretical framework (Miller \& Le Breton-Miller, 2011; Shepherd \& Haynie, 2009) as well as to support single arguments or hypotheses (Björnberg \& Nicholson, 2012; Sharma \& Irving, 2005; Vallejo, 2008). Looking at the conflicting identities in family firms, Shepherd and Haynie (2009) introduce the 'family business meta-identity', which exists at the intersection of family and business identities. The meta-identity "represents the structure through which conflict at the intersection” (Shepherd \& Haynie, 2009, p. 1246) of these conflicting two identities is resolved. Regarding social categories, the authors see ‘business ownership’ as a distinct category that people perceive they belong to. They refer to the idea of compartmentalising identities, when individuals invoke "different identities at different times in response to different contexts" (2009, p. 1251) to preserve the distinctiveness of each identity. Shepherd and Haynie view such mechanisms as "inadequate and inappropriate” (2009, p. 1252) for solving conflict between family and business identities. The authors argue that compartmentalisation would hinder family businesses from capitalising on the two concurrent identities. Boers and Nordqvist (2012) take this argument further, seeing family firms as a combination of the institutions 'family' and 'business', which both carry different identities. In their article, the authors build upon the argument by Albert and Whetten (1985) regarding hybrid-identity organisations that exhibit "two or more identities at the same time" (Albert \& Adams, 2002, p. 35). Boers and Nordqvist argue that especially the case of listed 
family companies is prone to showing such hybrid identity, with a public listing presenting a new utilitarian identity that adds to the old normative identity of the family firm. These two competing identities could be counterbalanced by each other as Albert and Adams (2002) demonstrate in the case of law firms. Through such counterbalancing, an organisation would be well equipped to survive in a changing environment.

Zellweger, Eddleston and Kellermanns (2010) see organisational identity as a further component and source of familiness. The concept of familiness (Habbershon \& Williams, 1999; Habbershon, Williams, \& MacMillan, 2003) builds on a resource-based view and is referred to as the "idiosyncratic firm level bundle of resources and capabilities resulting from the system interactions” (Habbershon et al., 2003, p. 452) between family and business. As Nordqvist explains, familiness itself can become a “unique resource” (2005, p. 287), providing the firm with a sustainable competitive advantage. Zellweger and colleagues (2010) build on the work of Sundaramurthy and Kreiner, who argue that "family identity is unique and therefore impossible to completely copy” (2008, p. 416), thereby providing a potential competitive advantage. Such a competitive advantage in family firms could also stem from identity confirmation, the subjective state of an individual whose "social and personal context is consistent with and thereby supportive of his or her 'self-defined' identities” (Milton, 2008, p. 1065). The confirmation of personal identity in a family firm could in itself become a “unique, hard to imitate source of excellence that may escape nonfamily firms” (2008, p. 1064). Looking further at social embeddedness (Granovetter, 1985) in family firms, the findings show that higher identification with the family does not automatically lead to higher performance. Le Breton-Miller, Miller and Lester (2011) find that the degree to which actors in the firm are embedded within the family and identify with it influences their stance towards the business. This embeddedness makes them more prone to agency than stewardship 
behaviour, resulting in "strategies of conservatism and sparse investment that serve only selfish family objectives” (2011, p. 704).

Several of the presented articles focus on potentially positive outcomes from conflicting and overlapping identities. Hugenberg and Bodehausen (2004) however argue that social identities partly inhibit each other, especially when the "identities in question provide conflicting normative standards” (2004, p. 234). Additionally, a recent article on regret in owner-manager decision-making by Hirigoyen and Labaki (2012) points at the difficulties of fully exhibiting both business and family identities. The authors propose a dual dimension of regret, both family and business based, linking it to experienced and expected regret. Such regret may be traceable to the identity conflicts that family business owners experience. One possible solution to the contradictory findings could be the work by Knapp and colleagues (2013). The authors found that members of family firms use 13 identity work tactics to manage boundaries between individual and organisational identities. Similar to the argument by Hugenberg and Bodehausen (2004), the authors propose amongst others a 'selective disassociation' with one of the present identities. Such an approach may be used to avoid regret on either business or family dimensions. The conscious or unconscious selection of which identity is more salient is also part of the article by Barnett, Eddleston and Kellermanns (2009). The authors draw on SIT and role theory to explore how the importance placed on family and career roles by business owners’ links to performance in family and non-family firms. Barnett and colleagues find that role salience has different effects in family and non-family firms. Career role salience was generally beneficial for family firms as it reflects higher levels of professionalism, whereas family role salience was associated with "family-based problems [...] such as nepotism” (Barnett et al., 2009, p. 47). Interestingly, the authors do not refer to emotional ownership of the business, but rather to the business owner's "psychological 
attachment to his or her career” (2009, p. 39). Thus, the career itself instead of the ownership status becomes an important part of the identity.

Looking at how SIT has been used in organisational research, one of its strengths lies in explaining the antecedents of identity building and the possible results of identity formation. Dyer and Whetten (2006), for instance, use SIT to examine the effect of family ownership on corporate social performance (CSP). They find that family firms are more responsible than non-family firms due to their concern about image and reputation. Family business ownership seen as a social category is, in a way, impermeable, because family members "cannot switch family, if word of a shameful family activity” comes out (Dyer \& Whetten, 2006, p. 790). This accountability creates the need for family business owners to strengthen their social identity, hence acting more responsibly. The finding refers to the recent discussion about the motivation for group behaviour (Abrams \& Hogg, 2010), pointing out the importance of selfesteem as a driver for group behaviour. Block’s article (2010) on downsizing in family business uses a similar argumentation. The author looks at the effects of family management and ownership on the likelihood of downsizing in a company. He finds that family ownership has an impact on the probability of job cuts, whereas family management has no influence. Also Block builds on SIT, arguing that owners identify more strongly with their businesses and want to avoid actions that damage the reputation and thus harm their positive social identity. Block’s study identifies self-esteem as an important driver of group behaviour. Furthermore, Deephouse and Jaskiewicz (2013) look at the reputation of family and nonfamily firms. The authors integrate socioemotional wealth theory (Gómez-Mejía et al., 2007) and SIT. Interestingly, Gómez-Mejía and colleagues (2007) already saw the relationship between socioemotional wealth and identity, with socioemotional wealth fulfilling "the need for identification” (2007, p. 108) in family businesses. Deephouse and Jaskiewicz (2013) find that family businesses generally have a better reputation because family members identify 
more strongly with the business, especially when the family name is part of the firm's name (for more on reputation, see Chapter XX). Strengthening the reputation would thus also strengthen the self-image of the family members.

Regarding the birth of family firms, Brannon, Wiklund and Haynie (2013) investigate how relationships between romantic couples and biologically linked members in entrepreneurial teams influence the probability of ever reaching the point of first sales. Relying on SIT, the authors find that teams linked by family bonds and teams linked by love react differently when the "new identity of entrepreneur is imposed on the existing family identity" (2013, p. 125); couples are more likely to reach first sales as they are better able to cope with family and entrepreneurship identities by developing a meta-identity (Shepherd \& Haynie, 2009). Investigating the entrepreneurial orientation (EO) (Lumpkin \& Dess, 1996) in later stages of the family business, Miller and Le Breton-Miller (2011) as well as Miller, Le Breton-Miller and Lester (2011) link different identities to high or low EO and performance. While, for instance, lone founder owners and CEOs will embrace entrepreneurial identities that heighten EO and performance, post-founder family owners rather take on the identity of family nurturers, which goes along with lower levels of EO and performance. Family firm founders, however, will exhibit ‘blended identities’ (Shepherd \& Haynie, 2009), which go along with moderate levels of EO and performance.

While all of these articles focus on identity as regards family members, Carmon, Miller, Raile and Roers (2010) take SIT as a lens through which to examine the organisational identification of non-family employees. The identification depends on the perception of how the employees are treated, which is why organisational justice and the perceived similarity between the individual and the organisation come into focus; strong identification would accordingly lead to higher organisational commitment. Although the authors’ proposed model was not confirmed, the usage of identity theory for analysing non-family employees appears 
to be promising, as I will outline in the next section. The article by Fang, Randolph, Chrisman and Barnett (2013) represents another interesting approach as it looks at religiosity in family firms by combining stakeholder theory (Donaldson \& Preston, 1995) and SIT. The authors argue that religious belief shapes the expectations of how firm managers should act and accordingly encourages behaviour that is compatible with the religious orientation of the owning family. Fang and colleagues derive the concept of 'bounded stakeholder salience', due to which stakeholders receive legitimacy that they would rightfully not exhibit, "based on their possession of characteristics valued by the coalition of family decision-makers” (2013, p. 255).

Overall, the topic of social identity in family businesses has a high potential to yield an interesting and in-depth understanding of family firms. Concepts such as the family business meta-identity (Shepherd \& Haynie, 2009) or the conceptualisation of family businesses as hybrid-identity organisations (Boers \& Nordqvist, 2012) are promising. Regarding identity formulation processes, SIT could yield further insights into how identities evolve and how both family and non-family members become socialised in the family business. Surprisingly, however, several aspects of SIT have been used rather scarcely. Primarily, SIT was used in the building process of identity, but intergroup conflicts, including between companies, have largely been ignored. SIT could thus provide a new perspective, for instance, on succession.

\section{The future of Social Identity Theory in family business research}

Being the owner of a company or a member of the owning family has been seen by several authors as a social category in itself. The argument of Hogg and Terry (2000) that groups have a prototypical scheme to which members adhere should thus apply to the category of the ownership family as well. Because the owner family is the most important group in the family business because they own and oftentimes also manage the business, it would be insightful to 
see whether new organisational members, especially in the top-management team (TMT), adhere, or wish to adhere, to the family prototype. Oftentimes, there is a close relationship between owner families and non-family managers, with the managers talking about 'marrying a business’ or being ‘treated like a son’ by the family’s patriarch (Pinhack \& Waldkirch, 2013). For a TMT-member, belonging to the psychological group of the owner family could yield a positive identification as the membership may be seen as prestigious in the organisation. Having the non-family TMT-member adhere to their group prototype could also be a way for the owner family to align him or her with the family ways and values. This strategy partly reflects the notion of Barbera and Hasso (2013), who talk about the importance of non-family employees being embedded in the company and the family. Hence, SIT could be a fruitful approach for understanding the socialisation of non-family managers in both business and family.

Moreover, the reasons why family successors adopt or reject the owner family prototype could be an interesting research focus. As Hall (2012) argued, successors are prone to being caught in between the wish to belong to the family, therefore adhering to the prototype, while at the same time pursuing individuation, thus rejecting the expected prototype. This notion reflects Sharma and Irving’s (2005) idea of behavioural modelling, which could be used to attract successors towards the owner family prototype. It is also consistent with Stavrou and Swiercz (1998), who propose a model of offspring intentions on joining the business, arguing that business socialisation starts as early as adolescence. Hence, this socialisation process is longitudinal and does not start or end with the decision to join the business or even to take it over; Haag (2012) even argues for an everyday way of succession. The socialisation process could be especially insightful if investigated over a longer time period to understand how the social identity of young family members forms in regard to their family. As Schröder, Schmitt-Rodermund and Arnaud (2011) propose, it could be insightful to further integrate the 
grandparent generation and their influence on socialisation as well as the cultural differences that families are subject to. What could happen when the socialisation process fails was described by Kidwell, Kellermanns and Eddleston (2012). In their article on 'black sheep’ in family businesses, they describe cases of family members who go against the family prototype and display opportunistic behaviour, even damaging the business. It may therefore be important to better understand the socialisation process in family firms.

Another promising area for research in family businesses using SIT could be conflicts between several family groups in family firms. After several generational successions, it is likely that family businesses move into more complex ownership situations, such as 'cousin consortiums’ (Gersick, Lansberg, Desjardins, \& Dunn, 1999). Such a dispersion of ownership can be dangerous as oftentimes conflict broods between the different parts of the family. Lambrecht and Lievens (2008) argued that in such cases, it might be necessary to 'prune' the family tree to enable business continuity and family harmony. Another way to analyse such a conflict could be a stronger focus on intergroup conflict, as proposed by SIT. Particularly feelings of illegitimate inferiority between different family groups in the business that might have arisen due to different treatment by the parents could be a reason for intergroup conflict. SIT might provide new insights for owner families into how to act towards successors and how to divide ownership to inhibit these group conflicts. Moreover, the current insights into intergroup forgiveness could represent a fruitful approach when analysing requisites for reconciliation between feuding family groups. Van Tongeren and colleagues (2014), for instance, found that collective guilt and trust were the strongest facilitators of intergroup forgiveness; following this path, there may be much to learn about conflict in family firms.

The classic article about Scottish knitwear manufacturers and their cognitive perception of rivalry by Porac, Thomas and Baden-Fuller (1989) shows how the use of SIT could yield new insights regarding in-group bias in family firms. This paper could be seen as a family business 
paper, because the company size and location indicate that the majority of these companies were family-owned. Although the article was concerned with cognitive perception, the authors also refer to categorisation processes taking place that influenced how competition was perceived. Seeing their paper through the lens of SIT, in-group bias could possibly determine the manufacturers' perception of their environment. Thus, in-group bias could provide insights into why family firms form alliances or start rivalries with other businesses. An identity perspective could yield interesting insights combined with an institutional theory view of isomorphism (DiMaggio \& Powell, 1983). Isomorphism in family firms might possibly be explained by looking at similar identities and a possible transformation of group boundaries, as Gaertner and colleagues (1993) proposed.

To capture the influence of SIT in family firms, an interpretive qualitative approach might yield the necessary in-depth insight. In family business research, the interpretive approach is appropriate as the needs, motives, meanings, and rationales underlying interaction in the family firm are oftentimes "invisible and tacit - sometimes even unconscious to the family members themselves” (Nordqvist, Hall, \& Melin, 2009, p. 298). Trying, for instance, to understand the socialisation of non-family managers in both business and family, interpretive research might offer new understandings and help answer questions of how these processes unfold (Reay \& Zhang, 2014). At the core of an interpretive approach is the idea of verstehen (Weber, 1968), focusing on fine-grained details and how actors assign meaning, for example, to actions, events, or processes. It is the task of interpretation to clarify meaning, "to unearth that meaning” (Schwandt, 2007, p. 161) and to make it palpable to the audience. An interpretive approach allows for novel understandings, challenging the underlying assumptions and the reflection of one’s own research stance (Alvesson \& Sköldberg, 2009). One possible way to conduct such research could be a single case study approach, which is ideal for "gaining a deep understanding of dynamic processes", such as the formation of 
social identities (Reay \& Zhang, 2014, p. 579). As Dyer and Wilkins already argued, an indepth case study takes the context into consideration and provides a "rich description of the social scene” (1991, p. 615). Following one case over a longer period of time could enable the

researcher to "catch[...] reality in flight” (Pettigrew, 1990, p. 268). This would allow for what Brundin calls a real-time methodology, collecting the empirical material "at the same time as such data are unfolding” (2007, p. 281). Out of these insights, new theories about social identity formation or group dynamics in the family firm may arise.

\section{Conclusion and potential contributions to Social Identity Theory}

As already argued, the combination of SIT and family firms could yield many interesting insights. Yet, there are a few potential pitfalls in the use of SIT. First of all, in many cases issues of power may play an important role, such as in intergroup conflicts between different parts of the owner family. Relying only on SIT in these cases may not be enough to understand the unfolding events. Secondly, the differentiation between SIT and other theories, such as Culture Theory and Organisational Identity, can oftentimes be complicated as these theories look at the same levels of analysis and are oftentimes concerned with similar discussions. Having reviewed several family business articles, the boundaries between these theories were often blurry. It would go beyond the scope of this chapter to discuss how culture, organisational identity, power and SIT relate to each other. Yet, it is important to be aware of this pitfall when using SIT in research.

While SIT could yield new insights and understandings in family businesses, the specific case of family businesses could also provide new insights into SIT. For instance, the perception of the permeability of groups in SIT could be further developed through family business research, showing how non-family members might become part of the family owner group, thereby crossing an apparently impermeable border between groups. Furthermore, in the 
organisational research field, ownership has been ignored as an important variable in identity building. Strong ownership, as often found in family firms, could thus yield insights into the general role of ownership in organisational identity creation. Moreover, family firms are a fertile empirical ground for researching conflict and reconciliation, adding to the ongoing discussion of intergroup forgiveness in SIT. Concluding, the family business context is predisposed to the study of 'soft' phenomena; using SIT in family business research is therefore a logical choice that may offer new and exciting insights into family firms. 


\section{References}

Abrams, D. and Hogg, M. A., (2010), 'Social Identity and Self-Categorisation', In Dovidio, J. F., Hewstone, M., Glick, P., and Esses, V. M. (eds), The SAGE Handbook of Prejudice, Stereotyping and Discrimination London: SAGE Publications Ltd, pp. 179-193.

Albert, S. and Adams, E., (2002), 'The hybrid identity of law firms', In Moingeon, B. and Soenen, G. B. (eds), Corporate And Organisational Identities London ; New York: Routledge, pp. 35-50.

Albert, S. and Whetten, D. A., (1985), 'Organisational Identity', In Cummings, L. L. and Staw, B. M. (eds), Research in Organisational Behavior Vol. 7, JAI Press, pp. 263-295.

Alvesson, M. and Sköldberg, K., (2009), Reflexive Methodology : New Vistas for Qualitative Research 2. ed., Los Angeles ; London: SAGE.

Alvesson, M. and Willmott, H., (2002), 'Identity Regulation as Organizational Control: Producing the Appropriate Individual', Journal of Management Studies, 39 (5), 619644.

Ashforth, B.E. and Mael, F., (1989), 'Social Identity Theory and the Organization', The Academy of Management Review, 14 (1), 20-39.

Barbera, F. and Hasso, T., (2013), 'Do We Need to Use an Accountant? The Sales Growth and Survival Benefits to Family SMEs', Family Business Review, 26 (3), 271-292.

Barnett, T., Eddleston, K., and Kellermanns, F.W., (2009), 'The Effects of Family Versus Career Role Salience on the Performance of Family and Nonfamily Firms', Family Business Review, 22 (1), 39-52. 
Billig, M., (2002), 'Henri Tajfel’s “Cognitive aspects of prejudice” and the psychology of bigotry', British Journal of Social Psychology, 41 (2), 171-188.

Björnberg, Å. and Nicholson, N., (2012), 'Emotional Ownership The Next Generation’s Relationship With the Family Firm', Family Business Review, 25 (4), 374-390.

Blader, S.L. and Tyler, T.R., (2009), 'Testing and extending the group engagement model: Linkages between social identity, procedural justice, economic outcomes, and extrarole behavior.', Journal of Applied Psychology, 94 (2), 445-464.

Block, J., (2010), 'Family Management, Family Ownership, and Downsizing: Evidence From S\&P 500 Firms', Family Business Review, 23 (2), 109-130.

Boers, B. and Nordqvist, M., (2012), 'Understanding Hybrid-Identity Organizations: The Case of Publicly Listed Family Businesses', In Carsrud, A. and Brännback, M. (eds), Understanding Family Businesses New York: Springer, pp. 251-269.

Brannon, D.L., Wiklund, J., and Haynie, J.M., (2013), 'The Varying Effects of Family Relationships in Entrepreneurial Teams', Entrepreneurship Theory and Practice, 37 (1), 107-132.

Brown, R., (2000), 'Social identity theory: past achievements, current problems and future challenges', European Journal of Social Psychology, 30 (6), 745-778.

Brundin, E., (2007), 'Catching it as it happens', In Neergaard, H. and Ulhøi, J. P. (eds), Handbook of Qualitative Research Methods in Entrepreneurship Cheltenham, UK: Edward Elgar, pp. 279-307.

Carmon, A.F., Miller, A.N., Raile, A.N.W., and Roers, M.M., (2010), 'Fusing family and firm: Employee perceptions of perceived homophily, organizational justice, 
organizational identification, and organizational commitment in family businesses', Journal of Family Business Strategy, 1 (4), 210-223.

Chua, J.H., Chrisman, J.J., and Steier, L.P., (2003), 'Extending the Theoretical Horizons of Family Business Research', Entrepreneurship Theory and Practice, 27 (4), 331-338.

Deephouse, D.L. and Jaskiewicz, P., (2013), 'Do Family Firms Have Better Reputations Than Non-Family Firms? An Integration of Socioemotional Wealth and Social Identity Theories', Journal of Management Studies, 50 (3), 337-360.

DiMaggio, P.J. and Powell, W.W., (1983), 'The Iron Cage Revisited: Institutional Isomorphism and Collective Rationality in Organizational Fields', American Sociological Review, 48 (2), 147-160.

Donaldson, T. and Preston, L.E., (1995), 'The stakeholder theory of the corporation: Concepts, evidence, and implications', Academy of Management Review, 20 (1), 6591.

Dyer, W.G.J. and Whetten, D.A., (2006), 'Family Firms and Social Responsibility: Preliminary Evidence from the S\&P 500', Entrepreneurship Theory and Practice, 30 (6), 785-802.

Dyer, W.G.J. and Wilkins, A.L., (1991), 'Better stories, not better constructs, to generate better theory: A rejoinder to Eisenhardt', The Academy of Management Review, 16 (3), 613-619.

Ellemers, N., (1993), 'The Influence of Socio-structural Variables on Identity Management Strategies', European Review of Social Psychology, 4 (1), 27-57. 
Ellemers, N., Doosje, B., and Spears, R., (2004), 'Sources of respect: the effects of being liked by ingroups and outgroups', European Journal of Social Psychology, 34 (2), 155-172.

Fang, H., Randolph, R.V. de G., Chrisman, J.J., and Barnett, T., (2013), 'Firm religiosity, bounded stakeholder salience, and stakeholder relationships in family firms', Journal of Management, Spirituality \& Religion, 10 (3), 253-270.

Fleming, P. and Spicer, A., (2014), 'Power in Management and Organization Science', The Academy of Management Annals, 8 (1), 237-298.

Gaertner, S.L., Dovidio, J.F., Anastasio, P.A., Bachman, B.A., and Rust, M.C., (1993), 'The Common Ingroup Identity Model: Recategorization and the Reduction of Intergroup Bias', European Review of Social Psychology, 4 (1), 1-26.

Gersick, K. E., Davis, J. A., McCollum Hampton, M., and Lansberg, I., (1997), Generation to generation : life cycles of the family business Boston, Mass: Harvard Business School Press.

Gersick, K.E., Lansberg, I., Desjardins, M., and Dunn, B., (1999), 'Stages and Transitions: Managing Change in the Family Business', Family Business Review, 12 (4), 287-297.

Gleason, P., (1983), 'Identifying Identity: A Semantic History', The Journal of American History, 69 (4), 910.

Gómez-Mejía, L.R., Haynes, K.T., Núñez-Nickel, M., Jacobson, K.J., and Moyano-Fuentes, J., (2007), 'Socioemotional wealth and business risks in family-controlled firms: Evidence from Spanish olive oil mills', Administrative Science Quarterly, 52 (1), 106137. 
Granovetter, M., (1985), 'Economic action and social structure: the problem of embeddedness', American Journal of Sociology, 91 (3), 481-510.

Grant, D., Hardy, C., Oswick, C., and Putnam, L. L., (2004), 'Introduction: Organizational Discourse: Exploring the Field', In Grant, D., Hardy, C., and Putnam, L. L. (eds), The SAGE Handbook of Organizational Discourse London: SAGE Publications Ltd, pp. $1-37$.

Haag, Kajsa, (2012), Rethinking family business succession : from a problem to solve to an ongoing practice (dissertation), Jönköping Internatioal Business School.

Habbershon, T.G. and Williams, M.L., (1999), 'A Resource-Based Framework for Assessing the Strategic Advantages of Family Firms', Family Business Review, 12 (1), 1-25.

Habbershon, T.G., Williams, M., and MacMillan, I.C., (2003), 'A Unified Systems Perspective of Family Firm Performance', Journal of Business Venturing, 18 (4), 451465.

Hall, A., (2012), Family business dynamics : a role and identity based perspective Cheltenham: Edward Elgar.

Haslam, S. A., (2004), Psychology in Organizations - The Social Identity Approach Thousand Oaks, CA: Sage.

Hewstone, M., Cairns, E., Voci, A., Hamberger, J., and Niens, U., (2006), 'Intergroup Contact, Forgiveness, and Experience of “The Troubles” in Northern Ireland', Journal of Social Issues, 62 (1), 99-120. 
Hirigoyen, G. and Labaki, R., (2012), 'The role of regret in the owner-manager decisionmaking in the family business: A conceptual approach', Journal of Family Business Strategy, 3 (2), 118-126.

Hogg, M. A., (2007), 'Uncertainty-Identity Theory', In Mark P. Zanna (ed), Advances in Experimental Social Psychology Vol. Volume 39, Academic Press, pp. 69-126.

Hogg, M.A. and Adelman, J., (2013), 'Uncertainty-Identity Theory: Extreme Groups, Radical Behavior, and Authoritarian Leadership', Journal of Social Issues, 69 (3), 436-454.

Hogg, M.A. and Terry, D.J., (2000), 'Social Identity and Self-Categorization Processes in Organizational Contexts', Academy of Management Review, 25 (1), 121-140.

Hornsey, M.J., (2008), 'Social Identity Theory and Self-categorization Theory: A Historical Review', Social and Personality Psychology Compass, 2 (1), 204-222.

Hugenberg, K. and Bodenhausen, G.V., (2004), 'Category membership moderates the inhibition of social identities', Journal of Experimental Social Psychology, 40 (2), 233-238.

Kidwell, R.E., Kellermanns, F.W., and Eddleston, K.A., (2012), 'Harmony, Justice, Confusion, and Conflict in Family Firms: Implications for Ethical Climate and the “Fredo Effect”', Journal of Business Ethics, 106 (4), 503-517.

Knapp, J.R., Smith, B.R., Kreiner, G.E., Sundaramurthy, C., and Barton, S.L., (2013), 'Managing Boundaries Through Identity Work The Role of Individual and Organizational Identity Tactics', Family Business Review, 26 (4), 333-355. 
Lambrecht, J. and Lievens, J., (2008), 'Pruning the Family Tree: An Unexplored Path to Family Business Continuity and Family Harmony', Family Business Review, 21 (4), 295-313.

Le Breton-Miller, I., Miller, D., and Lester, R.H., (2011), 'Stewardship or Agency? A Social Embeddedness Reconciliation of Conduct and Performance in Public Family Businesses', Organization Science, 22 (3), 704-721.

Lumpkin, G.T. and Dess, G.G., (1996), 'Clarifying the entrepreneurial orientation construct and linking it to performance', Academy of Management Review, 21 (1), 135-172.

Miller, D. and Le Breton-Miller, I., (2011), 'Governance, Social Identity, and Entrepreneurial Orientation in Closely Held Public Companies', Entrepreneurship Theory and Practice, 35 (5), 1051-1076.

Miller, D., Le Breton-Miller, I., and Lester, R.H., (2011), 'Family and Lone Founder Ownership and Strategic Behaviour: Social Context, Identity, and Institutional Logics', Journal of Management Studies, 48 (1), 1-25.

Milton, L.P., (2008), 'Unleashing the Relationship Power of Family Firms: Identity Confirmation as a Catalyst for Performance', Entrepreneurship Theory and Practice, 32 (6), 1063-1081.

Nordqvist, M., (2005), 'Familiness in Top Management Teams: Commentary on Ensley and Pearson’s “An Exploratory Comparison of the Behavioral Dynamics of Top Management Teams in Family and Nonfamily New Ventures: Cohesion, Conflict, Potency, and Consensus”', Entrepreneurship Theory and Practice, 29 (3), 285-292. 
Nordqvist, M., Hall, A., and Melin, L., (2009), 'Qualitative research on family businesses: The relevance and usefulness of the interpretive approach', Journal of Management and Organization, 15 (3), 294-308.

Pettigrew, A.M., (1990), 'Longitudinal Field Research on Change: Theory and Practice', Organization Science, 1 (3), 267-292.

Pinhack, M. and Waldkirch, M., (2013), Just like a Marriage? Success Factors in the Relationship between the Non-Family CEO and the Owner Family, Master Thesis, Jönköping International Business School.

Porac, J.F., Thomas, H., and Baden-Fuller, C., (1989), 'Competitive Groups as Cognitive Communities: The Case of Scottish Knitwear Manufacturers', Journal of Management Studies, 26 (4), 397-416.

Reay, T. and Zhang, Z., (2014), 'Qualitative Methods in Family Business Research', In Melin, L., Nordqvist, M., and Sharma, P. (eds), The SAGE Handbook of Family Business 1. ed., Thousand Oaks, CA: SAGE Publications Ltd, pp. 573-593.

Reicher, S., Spears, R., and Haslam, A., (2010), 'The Social Identity Approach in Social Psychology', In Wetherell, M. and Mohanty, C. T. (eds), The Sage handbook of identities 1. ed., Thousand Oaks, CA: SAGE Publications, pp. 45-63.

Schröder, E., Schmitt-Rodermund, E., and Arnaud, N., (2011), 'Career Choice Intentions of Adolescents With a Family Business Background', Family Business Review, 24 (4), $305-321$.

Schwandt, T. A., (2007), The SAGE dictionary of qualitative inquiry 3. ed., Los Angeles, CA; London: SAGE. 
Sedikides, C. and Brewer, M. B., (2001), 'Individual Self, Relational Self, and Collective Self Partners, Opponents, or Strangers?', In Sedikides, C. and Brewer, M. B. (eds), Individual self, relational self, collective self, Philadelphia, PA: Psychology Press, pp. $1-6$.

Sharma, P. and Irving, P.G., (2005), 'Four Bases of Family Business Successor Commitment: Antecedents and Consequences', Entrepreneurship Theory and Practice, 29 (1), 1333.

Shepherd, D.A. and Haynie, J.M., (2009), 'Family Business, Identity Conflict, and an Expedited Entrepreneurial Process: A Process of Resolving Identity Conflict', Entrepreneurship Theory and Practice, 33 (6), 1245-1264.

Stavrou, E.T. and Swiercz, P.M., (1998), 'Securing the Future of the Family Enterprise: A Model of Offspring Intentions to Join the Business', Entrepreneurship: Theory \& Practice, 23 (2), 19-39.

Sundaramurthy, C. and Kreiner, G.E., (2008), 'Governing by Managing Identity Boundaries: The Case of Family Businesses', Entrepreneurship Theory and Practice, 32 (3), 415436.

Tagiuri, R. and Davis, J.A., (1992), 'On the Goals of Successful Family Companies', Family Business Review, 5 (1), 43-62.

Tagiuri, R. and Davis, J.A., (1996), 'Bivalent Attributes of the Family Firm', Family Business Review, 9 (2), 199-208.

Tajfel, H., (1969), 'Cognitive Aspects of Prejudice', Journal of Social Issues, 25 (4), 79-97. 
Tajfel, H., (1970), 'Experiments in intergroup discrimination', Scientific American, 223 (5), 96-102.

Tajfel, H., (1972), 'La catégorisation sociale', In Moscovici, S. (ed), Introduction à la psychologie sociale Vol. 1, Paris: Librairie Larousse, pp. 272-302.

Tajfel, H., Billig, M.G., Bundy, R.P., and Flament, C., (1971), 'Social categorization and intergroup behaviour', European Journal of Social Psychology, 1 (2), 149-178.

Tajfel, H., Fraser, C., and Jaspars, J. M. F., (1984), 'The social dimension in European social psychology', In Tajfel, H. (ed), The Social Dimension: Volume 1: European Developments in Social Psychology Cambridge University Press, pp. 1-9.

Tajfel, H. and Turner, J. C., (1979), 'An integrative theory of intergroup conflict', In Austin, W. G. and Worchel, S. (eds), The Social Psychology of Intergroup Relations Vol. 33, Monterey, CA: Brooks/Cole, pp. 38-43.

Turner, J. C., (1984), 'Social identification and psychological group formation', In Tajfel, H. (ed), The social dimension: European developments in social psychology Vol. 2, Cambridge, England: Cambridge University Press, pp. 518-538.

Vallejo, M.C., (2008), 'Is the Culture of Family Firms Really Different? A Value-based Model for Its Survival through Generations', Journal of Business Ethics, 81 (2), 261279.

Van Tongeren, D.R., Burnette, J.L., O’Boyle, E., Worthington, E.L., and Forsyth, D.R., (2014), 'A meta-analysis of intergroup forgiveness', The Journal of Positive Psychology, 9 (1), 81-95. 
Vignoles, V. L., Schwartz, S. J., and Luyckx, K., (2011), 'Introduction: Toward an Integrative View of Identity', In Schwartz, S. J., Luyckx, K., and Vignoles, V. L. (eds), Handbook of Identity Theory and Research Springer New York, pp. 1-27.

Weber, M., (1968), Economy and society: An outline of interpretive sociology 3. ed., Totowa NJ: Bedminster Press.

Wetherell, M., (2010), 'The Field of Identity Studies', In Wetherell, M. and Mohanty, C. T. (eds), The SAGE Handbook of Identities Thousand Oaks, CA: SAGE Publications, pp. $3-26$.

Whetten, D. A., Foreman, P., and Dyer, W. G., (2014), 'Organizational Identity and Family Business', In Melin, L., Nordqvist, M., and Sharma, P. (eds), The SAGE Handbook of Family Business 1. ed., Thousand Oaks, CA: SAGE Publications Ltd, pp. 480-497.

Wohl, M.J.A., Branscombe, N.R., and Klar, Y., (2006), 'Collective guilt: Emotional reactions when one’s group has done wrong or been wronged', European Review of Social Psychology, 17 (1), 1-37.

Zellweger, T.M. and Astrachan, J.H., (2008), 'On the Emotional Value of Owning a Firm', Family Business Review, 21 (4), 347-363.

Zellweger, T.M., Eddleston, K.A., and Kellermanns, F.W., (2010), 'Exploring the concept of familiness: Introducing family firm identity', Journal of Family Business Strategy, 1 (1), 54-63. 